\title{
First description of a Shiga toxin-producing Escherichia coli 0103:H2 strain isolated from sheep in Brazil
}

\author{
Fernando H. Martins ${ }^{1}$, Beatriz E.C. Guth², Roxane M.F. Piazza ${ }^{3}$, Jorge Blanco ${ }^{4}$, Jacinta S. Pelayo ${ }^{1}$ \\ ${ }^{1}$ Departamento de Microbiologia, Universidade Estadual de Londrina, Londrina, Brazil \\ ${ }^{2}$ Departamento de Microbiologia, Parasitologia e Imunologia, Universidade Federal de São Paulo, São Paulo, \\ Brazil \\ ${ }^{3}$ Laboratório de Bacteriologia, Instituto Butantan, São Paulo, Brazil \\ ${ }^{4}$ Laboratorio de Referencia de E. coli, Departamento de Microbiología y Parasitología, Facultad de Veterinaria, \\ Universidad de Santiago de Compostela, Lugo, Spain
}

Key words: STEC O103:H2; sheep; virulence features

J Infect Dev Ctries 2014; 8(1):126-128. doi:10.3855/jidc.3615

(Received 01 April 2013 - Accepted 12 June 2013)

Copyright (C) 2014 Martins et al. This is an open-access article distributed under the Creative Commons Attribution License, which permits unrestricted use, distribution, and reproduction in any medium, provided the original work is properly cited.

\section{Introduction}

Shiga toxin-producing Escherichia coli (STEC) comprise an important group of zoonotic pathogens causing a broad spectrum of disorders in humans, including mild to severe diarrhea, hemorrhagic colitis (HC) and the life-threatening condition hemolytic uremic syndrome (HUS). Although most outbreaks and sporadic cases of STEC have been attributed to strains belonging to serotype $\mathrm{O} 157: \mathrm{H} 7$, the frequency of non-O157 STEC infections is increasing in several regions [1]. More than 400 non-O157 STEC serotypes have been described so far and a considerable proportion of them have been linked to human illness $[1,2]$. In Brazil, human infections due to STEC are mainly associated with non-O157 serotypes, of which $\mathrm{O} 26: \mathrm{H} 11, \mathrm{O} 103: \mathrm{H} 2$ and $\mathrm{O} 111: \mathrm{H} 8 / \mathrm{H}-$ (non-motile) accounted for the majority of cases [3-5].

STEC O103:H2 was first described as a causative agent of HUS in 1992 [6]. Since then, serotype O103:H2 has been implicated either in outbreaks or in sporadic cases of gastroenteritis and HUS in Europe [7,8], Japan [9] and the United States [10,11]. In Brazil, STEC O103:H2 was isolated for the first time in 1986, and re-emerged years later as causative agent of infantile diarrhea and hemolytic anemia [4,5]. Despite the fact that multiple STEC strains have already been isolated from farm animals, such as cattle [12] and pigs [13] in Brazil, none of them belonged to the known pathogenic serotype O103:H2 and did not display the virulence repertoire commonly associated with severe human disease (i.e., stx plus eae and/or $e h x A$ genes). This is the first report of STEC O103:H2 isolated and characterized from animals in Brazil.

\section{The Study}

Ten sheep flocks located on southern Brazil were tested between April and September 2010. Fecal samples were collected from 130 healthy animals, streaked onto MacConkey agar and lactose-fermenting colonies were biochemically characterized as E. coli [14]. STEC strains were identified by detection of stxl, stx2, eae and ehxA virulence genes [15] and serotyped as previously described [16]. Twenty-three different STEC serotypes were detected (data not shown), including O103:H2, carrying stx1, eae and $e h x A$ genes which was isolated from a 4-week-old lamb. Intimin type $\varepsilon$ was identified in this strain [16]. The stxl eae- $\varepsilon$ ehxA virulence gene profile is commonly observed among STEC O103:H2 strains $[4,5,7,9]$. Stxl expression was confirmed by cytotoxicity and neutralization assays on Vero cells [17], and enterohemolysin production was evidenced by the appearance of lysis zone on washed sheep blood agar plates [17]. The genotypic and phenotypic characteristics observed were similar to those of O103:H2 strains previously isolated from patients with diarrhea and hemolytic anemia in Brazil (Table 1). 
Table 1. Characteristics of ovine STEC O103:H2 compared to human O103:H2 strains isolated in Brazil.

\begin{tabular}{|c|c|c|c|c|c|c|c|}
\hline \multirow{2}{*}{ Strain } & \multirow{2}{*}{ Serotype } & \multirow{2}{*}{ Origin $^{(1)}$} & \multicolumn{4}{|c|}{ Genotypic and phenotypic characteristics ${ }^{(2)}$} & \multirow{2}{*}{ Reference } \\
\hline & & & Virulence profile & Intimin type & Stx & Ehly & \\
\hline $\mathrm{JN} 2 \mathrm{~b}$ & $\mathrm{O} 103: \mathrm{H} 2$ & $\mathrm{~S}$ & stxl eae ehxA & $\varepsilon$ & + & + & This study \\
\hline $437 / 01$ & $\mathrm{O} 103: \mathrm{H} 2$ & HA & stxl eae ehxA & $\varepsilon$ & + & + & [4] \\
\hline $651-1$ & $\mathrm{O} 103: \mathrm{H} 2$ & HD & stxl eae ehxA & $\varepsilon$ & + & + & {$[4]$} \\
\hline $495-12$ & $\mathrm{O} 103: \mathrm{H} 2$ & $\mathrm{HD}$ & stxl eae ehxA & $\varepsilon$ & + & + & {$[4,5]$} \\
\hline 91 & $\mathrm{O} 103: \mathrm{H} 2$ & $\mathrm{HD}$ & stx 1 stx2 eae ehxA & $\varepsilon$ & + & + & [4] \\
\hline
\end{tabular}

${ }^{(1)}$ S: sheep; HA: hemolytic anemia; HD: human diarrhea

${ }^{(2)}$ Stx: cytotoxic activity; Ehly: production of enterohemolyin

A low prevalence of STEC O103:H2 in sheep has been also documented in other studies [18], supporting our results and suggesting that the occurrence of this serotype in ovine seems to be uncommon. However, STEC O103:H2 outbreaks and sporadic cases have been traced to contact with animals [7] as well as to consumption of contaminated meat [11], indicating that transmission of strains belonging to this serotype can occur between animals and humans.

\section{Conclusion}

The potential role of animals in the epidemiology of STEC O103:H2 human infection is still poorly understood in Brazil. In the present study, we described for the first time the isolation and characterization of STEC O103:H2 of animal origin in this country. This strain exhibited virulence features similar to those of human clinical strains, suggesting that sheep may be carriers, albeit at low frequency, of potentially human-pathogenic STEC O103:H2. However, more studies are needed to establish sheep and other animal species as source of STEC O103:H2 infection in our settings.

\section{Acknowledgements}

This work was supported by grants from Coordenação de Aperfeiçoamento de Pessoal de Nível Superior (CAPESBrazil) and Conselho Nacional de Desenvolvimento Científico e Tecnológico (CNPq-Brazil).

\section{References}

1. Johnson KE, Thorpe CM, Sears CL (2006) The emerging clinical importance of non-O157 Shiga-toxin producing Escherichia coli. Clin Infect Dis 43: 1587-1595.

2. WHO (World Health Organization) (1998) Zoonotic nonO157 Shiga toxin-producing Escherichia coli (STEC), 23-26 June 1998. Berlin, Germany, Geneva, Switzerland: World Health Organization. W.H.O./CSR/APH/98.8-30

3. Vaz TM, Irino K, Kato MA, Dias AM, Gomes TA, Medeiros MI, Rocha MM, Guth BE (2004) Virulence properties and characteristics of Shiga toxin-producing Escherichia coli in São Paulo, Brazil, from 1976 through 1999. J Clin Microbiol 42: 903-905.
4. Guth BE, Vaz TM, Gomes TA, Chinarelli SH, Rocha MM, de Castro AF, Irino K (2005) Re-emergence of O103:H2 Shiga toxin-producing Escherichia coli infections in São Paulo, Brazil. J Med Microbiol 54: 805-806.

5. Irino K, Vaz TM, Medeiros MI, Kato MA, Gomes TA, Vieira MA, Guth BE (2007) Serotype diversity as a drawback in the surveillance of Shiga toxin-producing Escherichia coli infections in Brazil. J Med Microbiol 56: 565-567.

6. Mariani-Kurkdjian P, Denamur E, Milon A, Picard B, Cave H, Lambert-Zechovsky N, Loirat C, Goullet P, Sansonetti PJ, Elion J (1993) Identification of a clone of Escherichia coli O103:H2 as a potential agent of hemolytic-uremic syndrome in France. J Clin Microbiol 31:296-301.

7. Prager R, Liesegang A, Voigt W, Rabsch W, Fruth A, Tshape $\mathrm{H}$ (2002) Clonal diversity of Shiga toxin-producing Escherichia coli O103:H2/H- in Germany. Infect Genet Evol 1: 265-275.

8. Heinikainen S, Pohjanvirta T, Eklund M, Siitonen A, Pelkonen S (2007) Tracing Shigatoxigenic Escherichia coli O103, O145 and $\mathrm{O} 174$ infections from farm residents to cattle. J Clin Microbiol 45: 3817-3820.

9. Igushi A, Iyoda S, Ohnishi M, EHEC Study Group (2012) Molecular characterization reveals three distinct clonal groups among clinical shiga toxin-producing Escherichia coli strains of serogroup O103. J Clin Microbiol 50: 2894-2900.

10. Brooks JT, Sowers EG, Wells JG, Greene KD, Griffin PM, Hoekstra RM, Strockbyne MA (2005) Non-O157 Shiga toxinproducing Escherichia coli infections in the United States, 1983-2002. J Infect Dis 192: 1422-1429.

11. Rounds JM, Rigdon CE, Muhl LJ, Forstner M, Danzeisen GT, Koziol BS, Taylor C, Shaw BT, Smith KE (2012) Non-O157 Shiga toxin-producing Escherichia coli associated with venison. Emerg Infect Dis 18: 279-282.

12. Aidar-Ugrinovich L, Blanco J, Blanco M, Blanco JE, Leomil L, Dahbi G, Mora A, Onuma DL, Silveira WD, Pestana de Castro AF (2007) Serotypes, virulence genes, and intimin types of Shiga toxin-producing Escherichia coli (STEC) and enteropathogenic E. coli (EPEC) isolated from calves in São Paulo, Brazil. Int J Food Microbiol 115:297-306.

13. Borges CA, Beraldo LG, Maluta RP, Cardozo MV, Guth BE, Rigobelo EC, de Ávila FA (2012) Shiga toxigenic and atypical enteropathogenic Escherichia coli in the feces and carcasses of slaughtered pigs. Foodborne Pathog Dis 9: 11191125.

14. Irino K, Kato MA, Vaz TM, Ramos II, Souza MA, Cruz AS, Gomes TA, Vieira MA, Guth BE (2005) Serotypes and virulence markers of Shiga toxin-producing Escherichia coli (STEC) from dairy cattle in São Paulo State, Brazil. Vet Microbiol 105: 29-36.

15. Paton AW and Paton JC (1998) Detection and characterization of Shiga toxigenic Escherichia coli by using 
multiplex PCR assays for $s t x 1, s t x 2$, eaeA, enterohemorrhagic E. coli hlyA, rfbO111 and rfbO157. J Clin Microbiol 36: 598602.

16. Blanco M, Blanco JE, Mora A, Rey J, Alonso JM, Hermoso M, Hermoso J, Alonso MP, Dahbi G, González EA, Bernárdez MI, Blanco J (2003) Serotypes, virulence genes, and intimin types of Shiga toxin (verotoxin)-producing Escherichia coli isolates from healthy sheep in Spain. J Clin Microbiol 41: 1351-1356.

17. Mendes-Ledesma MR, Rocha LB, Bueris V, Krause G, Beutin L, Franzolin MR, Trabulsi LR, Elias WP, Piazza RM (2008) Production and characterization of rabbit polyclonal sera against Shiga toxins Stx1 and Stx2 for detection of Shiga toxin-producing Escherichia coli. Microbiol Immunol 52: 484-491.
18. Sekse C, Sunde M, Hopp P, Bruheim T, Cudjoe KS, Kvitle B, Urdahl AM (2013) Occurrence of potentially humanpathogenic Escherichia coli $\mathrm{O} 103$ in Norwergian sheep. Appl Environ Microbiol 79: 7502-7509.

\section{Corresponding author}

Jacinta Sanchez Pelayo. PhD.

Departamento de Microbiologia, Universidade Estadual de Londrina, Rodovia Celso Garcia Cid Pr 445 Km 380, Brazil Tel: (55-043) 3371-4494(Work)

Fax: (55-043) 3371-4291

Email: jspelayo@gmail.com

Conflict of interests: No conflict of interests is declared. 